IZA DP No. 9563

Initial Conditions Matter:

Social Capital and Participatory Development

Lisa Cameron

Susan Olivia

Manisha Shah

December 2015 


\title{
Initial Conditions Matter: Social Capital and Participatory Development
}

\author{
Lisa Cameron \\ Monash University and IZA \\ Susan Olivia \\ Monash University \\ Manisha Shah \\ University of California, Los Angeles, NBER and IZA
}

\author{
Discussion Paper No. 9563 \\ December 2015
}

\author{
IZA \\ P.O. Box 7240 \\ 53072 Bonn \\ Germany \\ Phone: +49-228-3894-0 \\ Fax: +49-228-3894-180 \\ E-mail: iza@iza.org
}

Any opinions expressed here are those of the author(s) and not those of IZA. Research published in this series may include views on policy, but the institute itself takes no institutional policy positions. The IZA research network is committed to the IZA Guiding Principles of Research Integrity.

The Institute for the Study of Labor (IZA) in Bonn is a local and virtual international research center and a place of communication between science, politics and business. IZA is an independent nonprofit organization supported by Deutsche Post Foundation. The center is associated with the University of Bonn and offers a stimulating research environment through its international network, workshops and conferences, data service, project support, research visits and doctoral program. IZA engages in (i) original and internationally competitive research in all fields of labor economics, (ii) development of policy concepts, and (iii) dissemination of research results and concepts to the interested public.

IZA Discussion Papers often represent preliminary work and are circulated to encourage discussion. Citation of such a paper should account for its provisional character. A revised version may be available directly from the author. 
IZA Discussion Paper No. 9563

December 2015

\section{ABSTRACT \\ Initial Conditions Matter: Social Capital and Participatory Development ${ }^{*}$}

Billions of dollars have been spent on participatory development programs in the developing world. These programs give community members an active decision-making role. Given the emphasis on community involvement, one might expect that the effectiveness of this approach would depend on communities' pre-existing social capital stocks. Using data from a large randomised field experiment of Community-Led Total Sanitation in Indonesia, we find that villages with high initial social capital built toilets and reduced open defecation, resulting in substantial health benefits. In villages with low initial stocks of social capital, the approach was counterproductive - fewer toilets were built than in control communities and social capital suffered.

JEL Classification: $\quad 012,022, \mathrm{I} 15$

Keywords: participatory development, social capital, sanitation, economic development, Indonesia

Corresponding author:

Lisa Cameron

Department of Econometrics and Business Statistics

Monash University

3800 Victoria

Australia

E-mail: lisa.cameron@monash.edu

\footnotetext{
* We are grateful to the Bill and Melinda Gates Foundation for funding the initial impact evaluation which provides the baseline and endline data, and the Australian Research Council for funding the social capital module (ARC Discovery Project DP0987011). We would like to thank Joseph Cummins, John Strauss, and participants at seminars at the University of Southern California, Georgetown University and the World Bank for helpful comments.
} 


\section{Introduction}

Participatory development (PD) strategies seek to engage local populations in development projects. The poor are given a role in initiatives designed for their benefit in the hope that development projects will be more sustainable and successful if local populations are engaged in the development process. PD has become an increasingly accepted method of development practice and is widely employed by a variety of organisations. It is often presented as an alternative to mainstream "top-down" development. A significant share of development assistance from international agencies, governments and non-government organisations is now directed via PD projects. Over the past decade, the World Bank has allocated almost \$85 billion to local participatory development (Mansuri and Rao, 2012).

Given PD projects' emphasis on community involvement, one might expect that they would function best in communities with high pre-existing levels of social capital - defined here as the norms and networks that enable collective action. ${ }^{1}$ A higher level of social capital is thought to facilitate collective action by lowering the costs associated with such action (Casey et al., 2012); by reducing the problem of free riding; and facilitating the transmission of knowledge about the behaviour of others and hence reducing the problems of opportunism (Collier, 1998). Communities with higher levels of trust and a greater degree of pre-existing community interaction are likely to be better prepared to cooperate and also have a greater store of community knowledge on which to draw when targeting the poor and prioritizing community needs. Conversely, communities with low stocks of social capital, with fewer interactions between community members, fewer community groups, and lower levels of trust might struggle to work together and agree on community priorities. Research on the relationship between initial levels of social capital and PD performance is almost non-existent and where it does exist, data limitations mean that the direction of causality

\footnotetext{
${ }^{1}$ Many related definitions of social capital exist. They generally incorporate preferences that inform interactions amongst individuals in a pro-social manner, such as altruism, trust and reciprocity; and/or a set of underlying community networks that can be used by individuals for private or public benefit (Durlauf and Fafchamps, 2005). See also Putnam et al. (1993), Coleman (1988) and Grootaert et al. (2002).
} 
is not clearly identified (see for example Isham and Kähkönen (1999, 2002); Pargal et al. $(1999)) .^{2}$

In this paper we explore whether social capital enhances PD effectiveness in the context of a large scale randomised evaluation of a Community-Led Total Sanitation (CLTS) program in rural East Java, Indonesia. Data from a detailed social capital module allow us to construct social capital indices pre- and post-intervention (approximately two years apart). We find that high pre-existing levels of community participation are strongly positively associated with program outcomes, measured by the rate of toilet construction and open defecation, which in turn lead to improvements in child health. We present evidence consistent with higher community participation at baseline being associated with better project outcomes because communities with higher levels of pre-existing social capital are better able to apply social sanctions. In more close-knit communities, people are more likely to care about what their fellow community members say and think of them, making social sanctions more effective. In communities with low levels of baseline social capital (bottom 20\%), fewer toilets were constructed than in control communities. These results are robust to the inclusion of a wide set of village controls.

In addition to seeking to improve living standards in poor communities, PD projects are often explicitly viewed as a vehicle for building social capital. By empowering communities and providing a reason and process by which community members can work together for a common goal, PD provides a potential mechanism for increasing community member interactions, forging relationships and building trust (Avdeenko and Gilligan, 2015). ${ }^{3}$ In the long-run, gains in social capital might facilitate economic development and help to sustain

\footnotetext{
${ }^{2}$ Isham and Kähkönen $(1999,2002)$ use cross-sectional data from villages participating in communitybased water interventions in Indonesia; India and Sri Lanka, respectively, and find that higher levels of social capital are positively associated with greater household participation in the selection of the type of water infrastructure and construction monitoring, and that this can lead to greater health improvements. Pargal et al. (1999) find that social capital is positively associated with voluntary solid waste management systems arising in Dhaka, Bangladesh. Evidence from case studies is mixed (see Uphoff and Wijayaratna (2000)).

${ }^{3}$ Others argue that norms of social interactions only change slowly (Putnam et al., 1993; Bowles and Gintis, 2004) and are largely reflect relatively fixed characteristics of communities, such as ethnic heterogeneity or the distribution of wealth (Alesina and Ferrara, 2005).
} 
program impacts (Dongier et al., 2003; Mansuri and Rao, 2004)). Again, however, the literature is relatively thin and produces mixed results. (For surveys see Wong (2012); Mansuri and Rao $(2004,2012).)^{4}$

In the context of CLTS we find that the impact on social capital depends on the initial level of community participation. CLTS builds social capital in communities that are able to successfully harness the program because of their higher initial community participation. However, the program has a negative impact on social capital in communities with low initial community participation. Our results may explain why community driven development has not been successful in building social capital in post-conflict zones as levels of social capital may be low in such areas.

Understanding where PD works and where it does less well has important welfare consequences. We demonstrate that where CLTS led to decreases in open defecation, diarrhoea prevalence among young children was significantly reduced and there were height and weight gains. Utilizing such approaches in communities with the requisite social capital thus stands to significantly improve health outcomes. However, in communities that are not equipped to be able to rally the community to achieve the program's aims, PD can be detrimental. If participatory development approaches are to be used in low social capital settings, our results suggest more intense involvement of project facilitators and general project support may be warranted in villages with demonstrably low social capital.

The rest of the paper is organised as follows. Section 2 describes the intervention and the data. Section 3 describes the empirical strategy and results. Section 4 concludes.

\footnotetext{
${ }^{4}$ The evidence on relatively politically stable and conflict-free settings, similar to our study site, is mixed. The Jamaican Social Fund was found to increase trust and the capacity for collective action (Rao and Ibanez, 2005). The World Bank's Philippines Community Driven Development program had a negative impact on collective action, but a positive impact on trust, participation in village assemblies, and the willingness of households to contribute money for community activities (Labonne and Chase, 2011). Pradhan et al. (2010) find no impact of the Indonesia Urban Poverty Program (II) on community participation, organization membership, or participation in community-initiated activities in treatment communities. These studies all use matching methods to construct control groups. Findings for post-conflict zones uniformly find no impact of community driven development on non-project collective activities (see Casey et al. (2012); Humphreys et al. (2013); Barron (2010); Avdeenko and Gilligan (2015); Fearon et al. (2009) in the contexts of Sierra Leone; Democratic Republic of Congo; Aceh, Indonesia; Sudan; and Liberia respectively).
} 


\section{Background and Data}

\subsection{Background on CLTS}

Pioneered in Bangladesh in 1999, CLTS has now been widely implemented throughout Asia, Latin America, and Sub-Saharan Africa (Wells and Sijbesma, 2012). CLTS is a communityled approach that focuses on creating demand for sanitation, in contrast to the traditional approach of supplying sanitation hardware (Sah and Negussie, 2009). CLTS facilitators are sent to villages to initiate a community analysis of existing sanitation practices and a discussion of the negative health consequences of such practices. The community actively participates in the facilitated meeting and is then left to forge its own plan to improve village sanitation with only limited follow-up support and monitoring from the program. These discussions, or "triggerings" are held in public places and are open to all. They involve a "walk of shame," during which the facilitator helps people analyze how faecal contamination spreads from exposed excreta to their living environments and food and drinking water. A map of the village is drawn on the ground and villagers are asked to indicate where they live, where they defecate, and the routes they take there and back. This illustrates that everyone is ingesting small amounts of each other's faeces which is intended to lead to personal and collective decisions to improve community health by becoming an open defecation free (ODF) community. In contrast to other approaches that have been used widely in the past in Indonesia and elsewhere, no funding for infrastructure or subsidies of any kind is provided. ODF status is verified by local government agencies and community members. ${ }^{5}$ CLTS has been found to increase the rate of toilet construction and decrease the prevalence of open defecation (Cameron et al., 2013; Gertler et al., 2015; Pattanayak et al., 2010; Patil et al., 2014; Hammer and Spears, 2013).

In the context of sanitation, social capital may enhance program effectiveness by low-

\footnotetext{
${ }^{5}$ In Indonesia the program is called Total Sanitation and Sanitation Marketing (TSSM) or in Indonesian Sanitasi Total \& Pemasaran Sanitasi (SToPS). It consists of a CLTS demand-side component and also a supply-side component which seeks to support the development of the local sanitation market. The supplyside component was however not well developed at the time of the evaluation (Cameron et al., 2013).
} 
ering the costs of collective action and by providing greater access to information on the community's needs. High levels of social capital within a community may also result in households internalizing the social benefit of the provision of private goods (Karlan, 2005). If a household builds a toilet and stops defecating in the village stream then other villagers benefit from this. If communities with higher levels of social capital internalise these social benefits more, they are likely to be more interested and willing to work together to improve the community's sanitation. Reports from fieldworkers suggest that the CLTS approach is particularly effective in settlements with a sense of community (Chambers, 2009).

\subsection{Data}

CLTS in Indonesia was rolled out across rural areas in the province of East Java. East Java is Indonesia's second most populous province containing approximately 38 million residents. Eight of the 29 rural districts in East Java were involved in the original impact evaluation. In each district ten villages were randomly selected to participate in CLTS and ten were randomly selected to act as comparison villages. Randomization was stratified by subdistrict. ${ }^{6}$

Two waves of surveys were conducted. The baseline survey was conducted just prior to program implementation in August-September 2008. Within each village, approximately thirteen households were randomly selected to be surveyed.The endline data collection was conducted approximately 24 months later, between November 2010 and February 2011. The surveys collected a wide variety of information on the households including demographic information, a detailed sanitation module (including observations of household sanitation facilities), and a child health module (including anthropometric measurements). Given the interest in child health, surveyed households were required to have at least one child under the age of five at baseline and households with children under the age of two were prioritised. Community level demographic data and information on infrastructure was also collected.

\footnotetext{
${ }^{6}$ For further detail on the randomization design and process see Cameron et al. (2013).
} 
In addition, and most importantly for this study, a social capital module was conducted. Budgetary considerations however restricted the social capital module to a randomly chosen six of these eight districts. Our sample thus consists of approximately 1600 households spread across 120 rural villages in six districts. ${ }^{7}$

\subsubsection{Constructing Social Capital Indices}

Table 1 provides details of the social capital survey data collected at baseline and endline. It includes information on the extent of networks and participation; trust and cohesiveness; and crime and corruption. Given the large number of social capital variables in Table 1, there is the possibility of over rejection of the null hypothesis if we examine the impact of each variable separately, due to the problem of multiple inference (Anderson, 2008). We deal with this by constructing indices from groups of variables. This "mean effects index approach" reduces the effective number of tests by identifying in advance which outcome variables to group together in testing a hypothesis (see Kling et al. (2007)). The mean effects index for a hypothesis captures the average relationship between the variable of interest and the $\mathrm{N}$ different measures grouped in the index. An advantage of this approach is that each index represents a single test so the probability of a false rejection does not increase as additional outcomes are added to the summary index. Also, mean index tests are potentially more powerful than individual level tests - multiple outcomes that approach marginal significance may aggregate into a single index that attains statistical significance (O'Brien, 1984). We group the social capital variables into the three major categories discussed above; those reflecting 1) community networks and participation; 2) trust and social cohesion; and 3) crime and corruption. Table 1 shows which variables fall under which index. We construct the indices at both baseline and endline.

\footnotetext{
${ }^{7}$ These six districts are spread across East Java, and include Blitar, Bonodowoso, Jombang, Ngawi, Probolinggo, and Situbondo. For a more in-depth description of the geographic context, see Cameron and Shah (2015).
} 
Participation and Networks Information about the existence of local civic organizations and respondents' involvement in these groups was collected. At baseline respondents were asked about religious groups, women's groups and rotating saving (arisan) groups. At endline this was expanded to include water and sanitation groups, community work, neighbourhood watch, rubbish management, and loan and savings groups. The surveys also asked respondents about the number of close friends that the respondent has in the community, along with whether there is any friend in the community that the respondent can go to if she/he needs to borrow money.

Trust and Cohesion The baseline and endline surveys also collected information on the level of trust and community cohesion within the community. Questions include whether money would be returned if accidentally dropped; willingness of the respondent to help community members in need; extent of trust across different ethnicities; willingness to leave a child with a neighbour; whether villagers ever meet and work together to improve the village; and whether villagers contribute sufficiently to public activities.

Crime and Corruption Information was collected at both baseline and endline on whether any member of the household had been a victim of crime (violent and non-violent crime). At endline, a question on the perception of community safety was added. Respondents were also asked whether people in the community need to pay to obtain services more quickly and whether village officials misappropriate money for their own purposes.

In constructing the mean effects index for each category, we follow the procedures used in Kling et al. (2007) and Casey et al. (2012). That is, we orient each outcome such that higher values indicate better outcomes; standardise outcomes into comparable units by translating each into standard deviation units (subtracting the mean and dividing by the standard deviation in the control group); and compile a summary index that gives equal weight to each individual outcome component. We use social capital indices calculated at the level 
of the household and at the village level. The village level indices are calculated from the village averages of the corresponding variables. Only if an index as a whole is found to be significantly related to the variable of interest will we then examine the underlying contributors to that index.

\subsubsection{Balance}

Table 2 shows that our social capital measures are balanced between treatment and control. There are no significant differences in any of the individual social capital variables, nor in the aggregated social capital indices at the household and village levels. This is true across the entire sample and also within the subsample of households who do not have sanitation at baseline (since we estimate some regressions below only for this sub-sample). Table A1 in the appendix additionally shows that access to sanitation, improved water sources and sanitation behaviour (hand-washing) is balanced at baseline. Cameron and Shah (2010) present tests of balance across treatment and control communities for an even wider array of baseline variables. There are no significant differences in most demographic and socioeconomic characteristics between treatment and control groups.

\section{Empirical Strategy and Results}

\subsection{Effect of Social Capital on Program Effectiveness}

To examine the impact of social capital on the success or otherwise of the sanitation program we regress the primary outcome measure (toilet construction between baseline and endline) on a treatment dummy and an interaction between treatment and an index of community social capital at baseline. ${ }^{8}$ We estimate the following equation:

$$
Y_{i j}=\alpha+\beta_{1} T_{j}+\beta_{2} T_{j} * S C_{j[B L]}+\beta_{3} S C_{j[B L]}+\gamma X_{i j}+\delta_{K}+\epsilon_{i j}
$$

\footnotetext{
${ }^{8}$ Households report whether they had a toilet. This report is verified at the end of the interview by an inspection of the household's sanitation facilities. We prefer this outcome measure to self-reported open defecation as the latter may suffer from reporting bias. We nevertheless also examine open defecation below.
} 
where $Y_{i j}$ is the outcome measure for household $i$ in village $j$ (a variable that equals one if the household constructed a toilet between baseline and endline, and 0 otherwise); $T_{j}$ is the treatment dummy, which equals 1 for households in the treatment group, and 0 otherwise; $S C_{j[B L]}$ is the measure of baseline village social capital, and $T_{j} * S C_{j[B L]}$ is an interaction term between the treatment status of the village and baseline social capital. $\delta_{K}$ is a set of sub-district (kecamatan) dummy variables which are included because the randomization was conducted at this level. In some specifications, we also include a vector of household and village characteristics $\left(X_{i j}\right)$ as additional right-hand side controls. $\epsilon_{i j}$ is the error term that is correlated within villages. All specifications allow for village-level clustering of the standard errors. We estimate this equation for households that had no private sanitation at baseline as these are the households which can improve their sanitation in response to the program. $\beta_{2}$ is the main parameter of interest. A positive and statistically significant value will indicate that treatment was more effective in communities with a higher level of social capital.

Baseline social capital is not randomly assigned, so it is possible that it is correlated with, and proxying for, other unobservable (or observable) characteristics of the villages that also affect program effectiveness. All specifications control for sub-district fixed effects so we are effectively comparing villages within the same sub-district, however it is still possible that treatment villages differ in ways, correlated with social capital, that affect program effectiveness. To assess the likelihood of this, in some specifications we include an additional array of village level controls. These include the land area of the village; the percentage of households that are farmers; the average educational status of household heads; the gini coefficient of per capita income in the village; whether there is a medical facility or secondary school within $5 \mathrm{kms}$ of the village; the percentage of households in the village with no sanitation at baseline; and whether a river flows through the village. We examine the sensitivity of our results to adding these controls.

It also remains possible that it is the social capital of individual households that drives 
toilet construction rather than the level of social capital within the village. For example, it may be that better connected households are more likely to build a toilet, rather than it being households in villages with closer connections on average that are more likely to build. To examine this possibility we examine the impact of adding a household index of social capital (calculated in the same way as the village level variables but using the household variables instead of village averages), and also interact household social capital with treatment.

The estimation results from equation (1) are reported in Table 3. Panel A reports the results for the overall social capital index while Panels B, C and D examine the role of participation, trust, and crime/corruption separately. In columns 1 and 2, we do not include any controls except for sub-district fixed effects. In column 3 we include a standard set of household controls (the number of adults and children in the household, the household head's age, educational attainment, per capita household income and dwelling characteristics) and community controls (the community population, the percentage of the community which is Muslim, whether there is a paved road to the nearest city, whether there is more than one ethnic group in the community and whether there is TV access within the village).

Table 3 shows that treatment did improve sanitation. The first column in Panel A shows the results from regressing toilet construction on a treatment dummy and sub-district fixed effects. It shows that households that did not have sanitation at baseline and were in treatment villages were approximately 6 percentage points more likely to build a toilet between baseline and endline than similar households in control villages. This is a $100 \%$ increase in the rate of toilet construction relative to control villages (the mean in control villages is $6.0 \%){ }^{9}$

Column 2 adds a measure of baseline social capital and its interaction with treatment, $T_{j} * S C_{j[B L]}$. The social capital measure used in Panel $\mathrm{A}$ is constructed from all the social capital variables. That is, it encompasses the extent of networks in the community, trust

\footnotetext{
${ }^{9}$ These point estimates differ from those reported in Cameron et al. (2013) because here we only use data from the six districts in which the social capital module was conducted. Program impact is greater in these six districts than across all eight original districts (6 percentage points versus 3.7 percentage points).
} 
and social cohesion and crime and corruption. Baseline social capital is not associated with better sanitation outcomes per se, though the coefficient is positive, but it is associated with better outcomes in treatment villages. A one standard deviation increase in the baseline social capital index is associated with approximately a 5 percentage point (88\%) increase in the probability that a household built a toilet (significant at the $5 \%$ level). This is a large increase and signifies substantial variation in program success dependent on the initial level of social capital. Column 3 includes household and community controls, and the coefficient becomes slightly smaller though not significantly so.

In column 4, when we add the additional village controls, the coefficient on the interaction between treatment and baseline social capital is very similar in value to that in Column 2 . That the inclusion of additional observable control variables does not significantly change the estimated coefficients for the variable of interest, suggests it is unlikely that the estimates are biased due to omitted and possibly unobservable variables (Altonji et al., 2005). In column 5 we include the interaction of household social capital and treatment. There is no evidence that household social capital is positively associated with toilet construction. Rather, it seems that residing in a community where social capital is strong increases the probability of building a toilet as a result of the program, regardless of the household's level of social capital. ${ }^{10}$

Panels B, C and D of Table 3 examine the role of participation in networks, trust and cohesion, and crime/corruption separately. The positive impact on CLTS outcomes is being driven by the extent of networks and community participation within villages. In Panel B one can see that the coefficient on the interaction between treatment and the village participation index is strongly significant and positive. Hence, active participation by households in village community groups prior to the program is associated with more toilets being built in these villages. In contrast, the interaction between treatment and social capital is not significant

\footnotetext{
${ }^{10}$ These results are also robust to including interactions of the village level controls with treatment (results available upon request). Table A2 in the appendix examines the relationship between baseline social capital and all of the village characteristics. Once controls for sub-district fixed effects are included, only village population is significantly (negatively) and meaningfully correlated with social capital.
} 
for the trust measure and the crime/corruption measure. ${ }^{11}$

\subsection{Open Defecation and Health Improvements}

Whether toilets are constructed is ultimately of concern only if these efforts are associated with health improvements. By working with communities to find sanitation solutions, CLTS seeks to improve community health, particularly child health. Child health stands to improve if toilet construction leads to decreases in open defecation and hence a reduction in faecal contamination in the village. We construct an index of open defecation behaviour from household reports of such behaviour. The respondent was asked whether men in the household defecate in the open daily; occasionally/seasonally; or never. The same question is asked about adult female household members and children under 5. To construct the open defecation index we assign a value of 0 to reports of never defecating in the open, 5 to occasional/seasonal open defecation and 10 to daily open defecation. We then add up the values for men, women and children and divide by 30 to create an index that lies in the range of 0 to 1 where 1 implies all men, women, and children in the household open defecate daily.

We re-estimate Equation (1) and report the same results from Panels A and B of Table 3 but with open defecation as the dependent variable in Table 4. The results for open defecation are similar to the toilet construction results. ${ }^{12}$ Table 4 shows that treatment reduced open defecation by approximately 8 percentage points (or 9 percent). Open defecation decreases even more in communities with higher social capital. Similar to Table 3, the social capital results are being driven by the participation index. For a one standard deviation increase in village participation social capital at baseline, open defecation decreases by an additional 9

\footnotetext{
${ }^{11}$ Table A3 in the appendix looks within this participation index to investigate which types of groups matter. All elements of the index are found to be positively associated with greater toilet construction in treatment villages, except for the number of close friends one has in the village. The results for participation in religious groups, arisan groups and having someone to borrow money from are statistically significant. Note that having someone to borrow money from captures both the positive effect of networks and that the ability to borrow makes it more feasible to build a toilet. Cameron et al. (2013) and Guiteras et al. (2015) show that credit constraints are a barrier to toilet construction for poor households.

${ }^{12}$ The results for Panels $\mathrm{C}$ and D are qualitatively similar as well to Table 3.
} 
percentage points in treatment villages which is about a 10 percent decrease.

Table 5 examines the impact of open defecation on child health outcomes. As open defecation is likely correlated with unobservables which also impact health outcomes, we employ 2SLS estimation. Our instruments for open defecation are the randomised treatment assignment status of the village, and interactions of assignment status with the baseline village participation index, and the baseline level of in-home sanitation coverage in the village. ${ }^{13}$ The dependent variables of interest are diarrhoea prevalence in the 7 days prior to the survey, weight for age z-scores and height for age z-scores for children aged 0-3 at baseline. We also include fixed effects for child age and gender, we control for baseline levels of the health outcome, and in some specifications include the standard set of household and community controls used in the previous estimations. ${ }^{14}$

Table 5 shows the impact of village open defecation on the child health outcomes. Columns 1, 4, and 7 report the reduced form OLS estimates, Columns 2, 5, and 8 report the IV estimates without controls and Columns 3, 6, and 9 report the IV estimates with controls. Sample sizes increase as some households have more than one child under 5 . The table indicates that decreasing open defecation significantly improves health outcomes. A one standard deviation increase in the open defecation index reduces diarrhoea prevalence by 3 percentage points or 0.17 standard deviations. The same decrease in open defecation is associated with a 0.26 standard deviation increase in the weight z-score and a 0.23 standard deviation increase in the height z-score. Thus the program stands to make significant contributions to human welfare in high community participation settings.

\footnotetext{
${ }^{13}$ Reductions in open defecation are the most obvious route via which the program leads to health impacts. The program could also potentially operate via increased handwashing, though handwashing is not the main focus of the facilitation sessions. Analysis of the data shows no significant treatment impacts on handwashing behaviour.

${ }^{14}$ We instrument for the village open defecation index (which is the average of the household defection index for all households in the village) because all of the instruments are at the village level. Using the household open defecation index yields similar results (available upon request).
} 


\subsubsection{Mechanisms: What drives the participation result?}

Table 6 explores the mechanisms behind the finding that greater participation in community groups prior to the program is associated with better program outcomes in treatment villages. We examine three hypotheses behind this result.

First, a more active community may mean a better informed community as members know each other better and exchange information when they meet. We test this hypothesis by examining whether villages with higher levels of baseline participation have greater information flows at endline. We construct an index of information shared within the community at endline from variables reflecting whether the household reported that they knew about the triggering event; learnt about sanitation construction from other community members; and increases in knowledge about the causes of diarrhoea between baseline and endline.

Second, in more active communities, people may be more willing to be actively involved and share resources as a result of knowing each other better. In the CLTS context this may result in being more likely to attend the triggering event and more shared and public toilets being built. To test this hypothesis we construct an index from these two variables and examine its relationship with the baseline village participation index.

Lastly, the final mechanism we examine is whether social sanctions play a greater role in encouraging households to build toilets in more active communities. If household members know their community better, they may be more concerned about what other community members think of them. We construct an index of sanctions from reports on a scale of 1 (strongly agree) to 5 (strongly disagree) on whether building a toilet reduces the likelihood of being a target of gossip; whether those who defecate in the open will not be accepted by the community; and whether the community imposes social sanctions on those who defecate in the open.

Table 6 reports the results of regressing each index (at endline) on the village participation index (at baseline). It shows that villages with higher levels of social capital at baseline are more likely to impose sanctions, consistent with these communities being more able to 
regulate behaviour by the use of social opprobria. The results in Column 1 and 2 do not support the thesis that higher baseline participation is associated with greater information, CLTS participation and shared/public toilet construction. ${ }^{15}$

To further examine the role of social pressure/sanctions in villages we examine the impact of the share of one's friends having a toilet on the decision to build a toilet. Table A4 reports the results. Whether friends have toilets is not associated with toilet construction in control villages, regardless of the extent of participation in community groups. In treatment villages having more friends with a toilet increases the probability of building a toilet and this effect is stronger in treatment villages that have higher rates of community participation. This is consistent with the "shaming" and peer-pressure that is part of CLTS being more effective in villages where people know each other better. In participatory development programs more generally, the ability to shame and apply social sanctions is likely to be important as it provides a stick with which to punish anti-social behaviour.

Figure 1 is a graphical representation of the estimated relationship between baseline community participation and toilet construction in treatment and control villages (using estimates from Table 3, Panel B, Column 4). It shows that in communities with higher levels of social capital, the probability of building a toilet increases. However, in communities with low levels of social capital (bottom $20 \%$ of the distribution) fewer toilets are constructed in treatment villages than in control villages. In the data, 11 percent of households constructed toilets in these low social capital treatment communities compared to 17 percent in similar control communities. This is consistent with community pressure to build toilets having adverse consequences in villages with low levels of community interaction. That is, in villages where people have less to do with one another, social sanctions and pressure may lead people to react against the message of the program. Intuitively this seems plausible as it is well-documented that people will often react against messages if they perceive that their behavioural freedom is threatened, termed "psychological reactance" (Brehm and Brehm,

\footnotetext{
${ }^{15}$ We also directly examined the construction of public and shared toilets. More active communities do not build more public and shared toilets.
} 
1981). The results constitute a caution about using PD approaches in low social capital settings. In summary, PD programs stand to make significant contributions to human welfare in high community participation settings but could equally have negative welfare implications if implemented in communities without the requisite social capital.

\subsection{Effect of CLTS Treatment on Social Capital}

Finally, we examine the impact of the program on social capital. We estimate the 'intention to treat' (ITT) program impact using the following regression equation:

$$
S C_{i j}=\alpha+\beta_{1} T_{j}+\beta_{2} S C_{i j[B L]}+\gamma X_{i j}+\delta_{K}+\epsilon_{i j}
$$

where $S C_{i j}$ is now the social capital measure for household $i$ in village $j$ at endline; and the other variables are as described above. All specifications allow for village-level clustering of the standard errors. $\beta_{1}$ is the parameter of interest and represents the effect of treatment on the various social capital indices.

Table 7 presents the results of estimating equation (2) for each of our social capital indices. Odd numbered columns present the regressions with no controls, even numbered columns include the standard set of controls used above. Baseline values of the relevant social capital index are also included.

The results in columns 1-2 show that treatment does not have a significant positive impact on overall social capital. The index combining all the available measures of endline social capital does not differ significantly between treatment and control communities. The coefficient on treatment is in fact negative but small and insignificant. Participation in community groups did not increase as a result of the program. Crime and perceptions of safety were similarly unaffected. The index measuring trust and social cohesion is significantly lower in treatment communities than control communities at endline. Treatment reduces trust by 0.1 standard deviations.

In Table A5 we disaggregate the trust index and examine each of its individual compo- 
nents. The coefficients on the treatment indicator variable are negative in six of the eight specifications (otherwise they are positive but insignificant) and treatment has a statistically significant negative impact on the reported ability of the community to work together and the willingness of the respondent to assist community members. It may be that by requiring the community to work together, the program has brought to the fore difficulties in this regard.

If this is the case we would expect to see trust decline more in communities where the program struggled to be successful i.e. villages with less active community participation at baseline. In Table 8 we test whether the impact of CLTS on social capital varies with the initial level of community participation. We re-estimate equation 1 interacting treatment with the baseline village participation index. The results indicate that in villages with a high level of participation at baseline, the negative trust result is ameliorated $(\mathrm{p}=0.06)$. For villages with baseline community participation in the top 15 percent, the program built trust. In all other communities, treatment was associated with a decrease in trust. Thus, in places where individuals are used to working together the program is quite effective and builds trust. Requiring individuals to work together in places where social capital levels are low however, can be counterproductive in terms of program goals (toilet construction, open defecation and health outcomes) and can have adverse impacts on the levels of trust within the community.

\section{Conclusion}

We study whether social capital impacts the effectiveness of a participatory development project. We find that having a high pre-existing degree of participation in community groups improves the likelihood of successful outcomes. We present evidence consistent with this operating through the greater ability of these communities to use social pressure to get community members to conform with program objectives. The participatory development program studied here was able to build toilets, reduce open defecation, improve child health 
and build social capital (trust) only in villages with high pre-existing community participation. In villages with initial low levels of community participation, the program was both ineffective (resulted in fewer toilets being built than in control villages) and had a negative impact on social capital.

These finding are cautionary with respect to using PD approaches in low social capital environments. At the very least, they suggest a need for greater investment in communitysupport for participatory development programs in areas with low social capital; or limiting the implementation of these types of programs to communities that already have high levels of social capital.

A final proviso, the program studied here - CLTS - is a relatively simple PD program with limited follow-up after the initial community meeting. Whether these results hold for PD programs with longer term community engagement, such as multi-year community driven development programs, is an area worthy of future research. 


\section{References}

Alesina, Alberto and Eliana La Ferrara, "Ethnic Diversity and Economic Performance," Journal of Economic Literature, 2005, 43 (3), 762-800.

Altonji, Joseph, Todd Tabler, and Christopher Taber, "Selection on observed and unobserved variables: Assessing the effectiveness of catholic schools," Journal of Political Economy, 2005, (113).

Anderson, Michael L, "Multiple inference and gender differences in the effects of early intervention: A reevaluation of the Abecedarian, Perry Preschool, and Early Training Projects," Journal of the American statistical Association, 2008, 103 (484), 1481-1495.

Avdeenko, Alexandra and Michael J. Gilligan, "International Interventions to Build Social Capital: Evidence from a Field Experiment in Sudan," American Political Science Review, 8 2015, 109, 427-449.

Barron, Patrick, "CDD in post-conflict and conflict-affected areas: experiences from East Asia," World Development Report 2011 Background Paper, 2010.

Bowles, Samuel and Herbert Gintis, "Persistent Parochialism: Trust and Exclusion in Ethnic Networks," Journal of Economic Behavior 6 Organization, September 2004, 55 (1), 1-23.

Brehm, Sharon S. and Jack W. Brehm, Psychological Reactance: A Theory of Freedom and Control, New York: Academic Press, 1981.

Cameron, Lisa and Manisha Shah, "Scaling up rural sanitation: findings from the impact evaluation baseline survey in Indonesia," 2010.

_ and _ , "Risk-taking in the Wake of Natural Disasters," The Journal of Human Resources, 2015, 50 (2), 484-515.

_, , and Susan Olivia, "Impact evaluation of a large-scale rural sanitation project in Indonesia," World Bank policy research working paper, 2013, (6360).

Casey, Katherine, Rachel Glennerster, and Edward Miguel, "Reshaping Institutions: Evidence on Aid Impacts Using a Preanalysis Plan," The Quarterly Journal of Economics, 2012, $127(4), 1755-1812$.

Chambers, Robert, "Going to Scale with Community-Led Total Sanitation: Reflections on Experience, Issues and Ways Forward," IDS Practice Paper, 2009.

Collier, Paul, "Social capital and poverty," Social Capital Initiative Working Paper, 1998, (4).

Dongier, Philippe, Julie Van Domelen, Elinor Ostrom, Andrea Rizvi, Wendy Wakeman, Anthony Bebbington, Sabina Alkire, Talib Esmail, and Margaret Polski, The Poverty Reduction Strategy Sourcebook, Vol. 1,

Durlauf, Steven and Marcel Fafchamps, "Social capital," in Philippe Aghion and Steven Durlauf, eds., Handbook of Economic Growth, Elsevier: Amsterdam, 2005, pp. 1639 - 1699. 
Fearon, James D, Macartan Humphreys, and Jeremy M Weinstein, "Can development aid contribute to social cohesion after civil war? Evidence from a field experiment in post-conflict Liberia," The American Economic Review, Papers and Proceedings, 2009, 99 (2), 287-291.

Gertler, Paul, Manisha Shah, Maria Laura Alzua, Lisa Cameron, Sebastian Martinez, and Sumeet Patil, "How Does Health Promotion Work? Evidence From The Dirty Business of Eliminating Open Defecation," 2015. NBER Working Paper.

Grootaert, Christiaan, Thierry Van Bastelaer et al., "Understanding and measuring social capital: A multidisciplinary tool for practitioners," 2002.

Guiteras, Raymond, James Levinsohn, and Mobarak Ahmed Mushfiq, "Encouraging sanitation investment in eth developing world: A cluster-randomized trial," Science, 2015, (348).

Hammer, Jeffrey and Dean Spears, "Village Sanitation and Children's Human Capital: Evidence from a Randomized Experiment by the Maharashtra Government," World Bank Policy Research Working Paper, 2013, (6580).

Humphreys, Macartan, Raul Sanchez de la Sierra, and Peter van der Windt, "Social and Economic Impacts of Tuungane: Final Report on the Effects of a Community Driven Reconstruction Program in Eastern Democratic Republic of Congo," 2013. 3ie Final Report.

Isham, Jonathan and Satu Kähkönen, "What Determines the Effectiveness of CommunityBased Water Projects? Evidence from Central Java, Indonesia on demand responsiveness, services rules and social capital," Social Capital Initiative Working Paper, 1999, 14.

_ and _, "Institutional Determinants of the Impact of Community-Based Water Services: Evidence from Sri Lanka and India," Economic Development and Cultural Change, April 2002, 50 (3), 667-91.

Karlan, Dean S, "Using experimental economics to measure social capital and predict financial decisions," American Economic Review, 2005, 95 (5), 1688-1699.

Kling, Jeffrey R, Jeffrey B Liebman, and Lawrence F Katz, "Experimental analysis of neighborhood effects," Econometrica, 2007, 75 (1), 83-119.

Labonne, Julien and Robert S Chase, "Do community-driven development projects enhance social capital? Evidence from the Philippines," Journal of Development Economics, 2011, 96 (2), 348-358.

Mansuri, Ghazala and Vijayendra Rao, "Community-based and-driven development: A critical review," The World Bank Research Observer, 2004, 19 (1), 1-39.

_ and _, "Localizing development: does participation work?," World Bank Policy Research Report, 2012.

O'Brien, Peter C, "Procedures for comparing samples with multiple endpoints," Biometrics, 1984, 40, 1079-1087.

Pargal, Sheoli, Mainul Huq, and Daniel Gilligan, "Social Capital in Solid Waste Management: Evidence from Dhaka, Bangladesh," Social Capital Initiative Working Paper No. 16, 1999. 
Patil, S.R., B.F. Arnold, A. Salvatore, B. Briceno, J.M. Colford Jr, and P.J. Gertler, "The Effect of India's Total Sanitation Campaign on Defecation Behaviors and Child Health in Rural Madhya Pradesh: A Cluster Randomized Controlled Trial," PLOS Medicine, 2014, 11 (8).

Pattanayak, S.K., C. Poulos, J.C. Yang, and S. Patil, "How valuable are environmental health interventions? Evaluation of water and sanitation programmes in India.," Bulletin of the World Health Organization, 2010, 88 (7), 481-560.

Pradhan, Menno, Vijayendra Rao, and Christina Rosemberg, "The Impact of the Community Level Activities of the Second Urban Poverty Project," mimeo, 2010.

Putnam, Robert D, Robert Leonardi, and Raffaella Nanetti, Making democracy work: Civic Traditions in Modern Italy, Princeton University Press, 1993.

Rao, Vijayendra and Ana Maria Ibanez, "The Social Impact of Social Funds in Jamaica: A ?Participatory Econometric? Analysis of Targeting, Collective Action, and Participation in Community-Driven Development," The Journal of Development Studies, 2005, 41 (5), 788-838.

Sah, S. and A. Negussie, "Community led total sanitation (CLTS): Addressing the challenges of scale and sustainability in rural Africa," Desalination, 2009, 248 (15), 666-672.

Uphoff, Norman and C. M. Wijayaratna, "Demonstrated Benefits from Social Capital: The Productivity of Farmer Organizations in Gal Oya, Sri Lanka," World Development, 2000, 28 (11), 1875-1890.

Wells, C. D. S. and C. Sijbesma, "Practical innovations for strengthening Community-Led Total Sanitation: selected experience from Asia," Development in Practice, 2012, 22 (3), 417426.

Wong, Susan, "What have been the impacts of World Bank Community-Driven Development Programs? CDD impact evaluation review and operational and research implications," Washington, D.C.: The World Bank, 2012. 


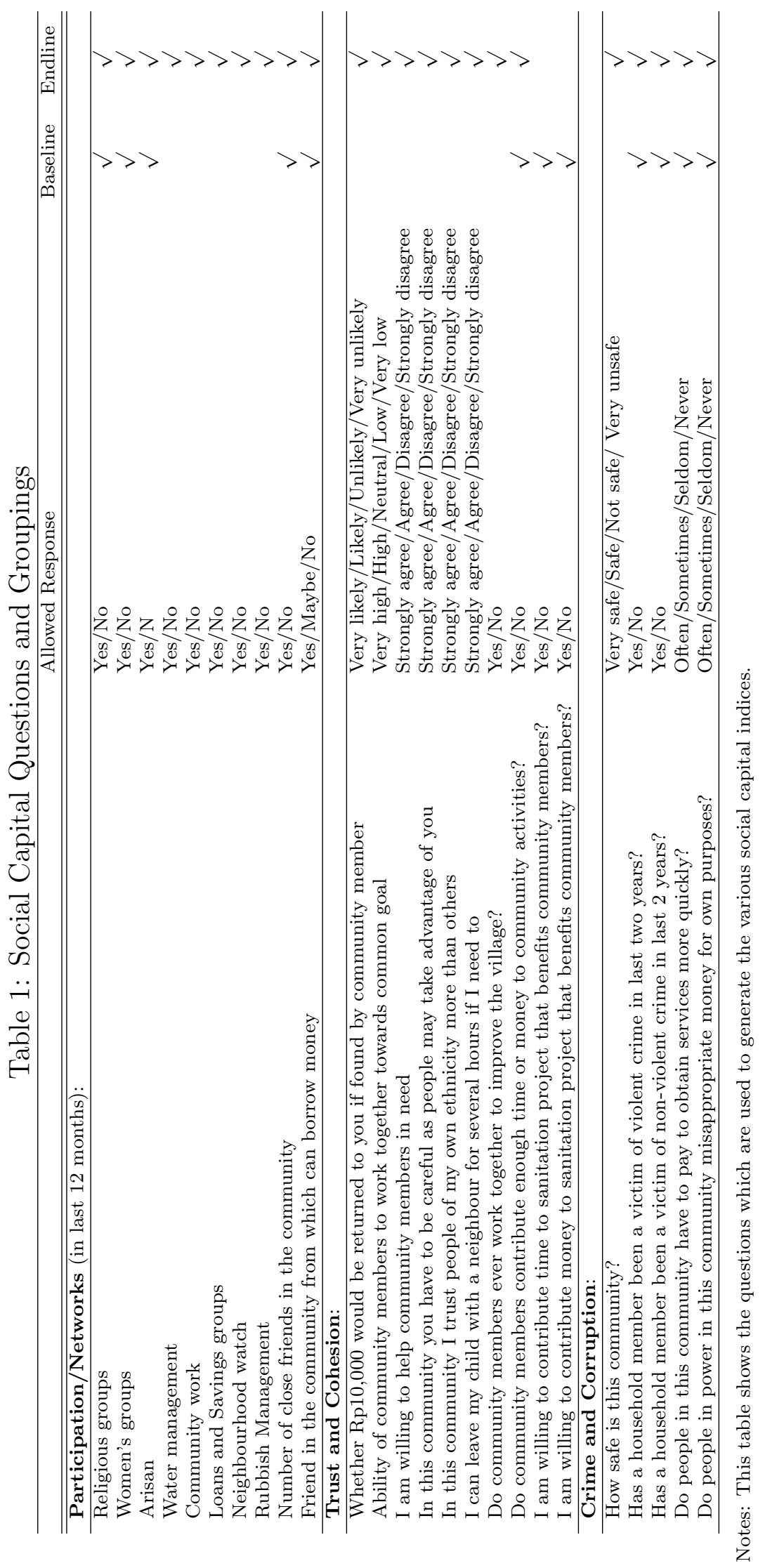




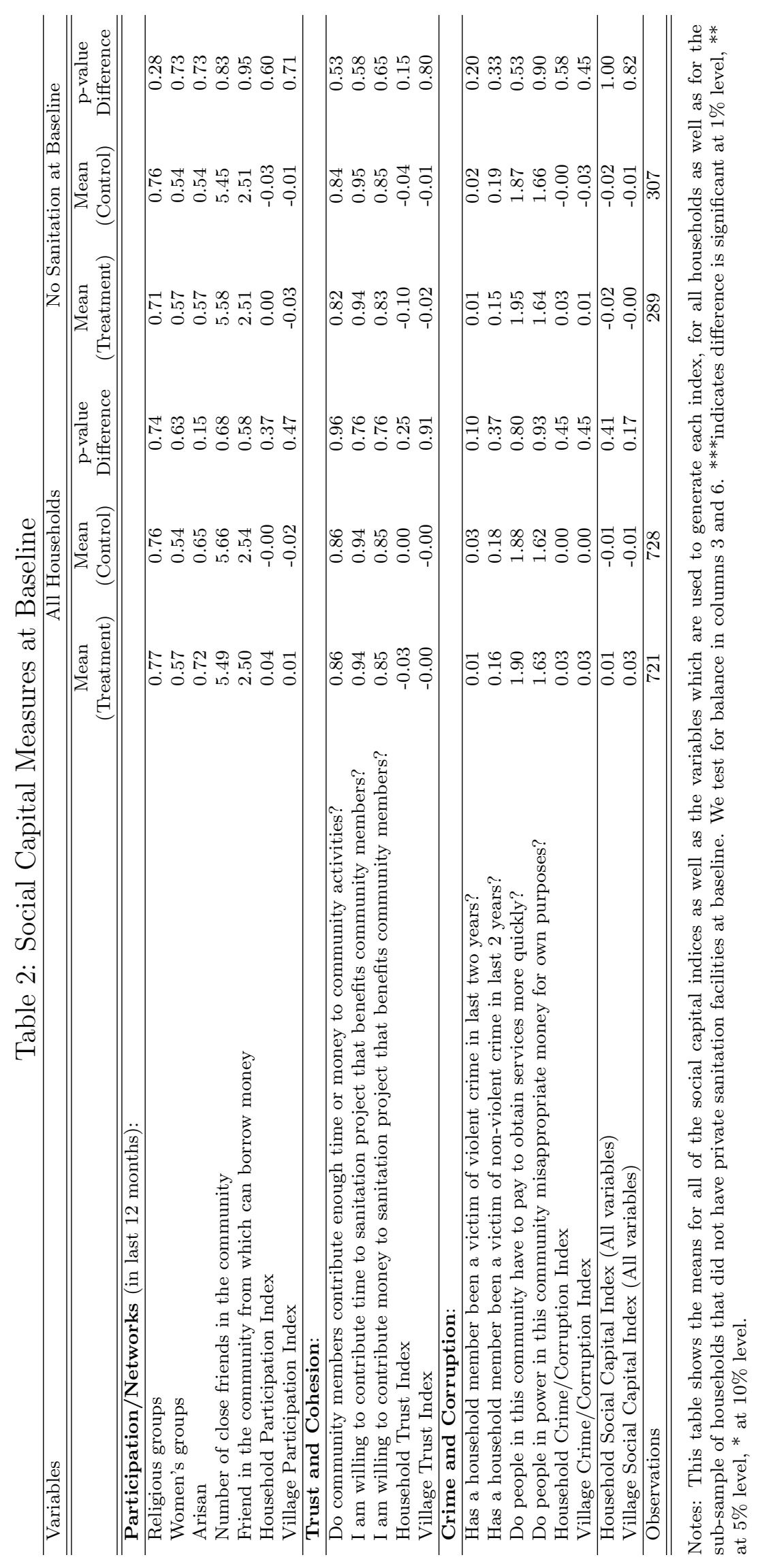


Table 3: Is social capital important for program success?

\begin{tabular}{|c|c|c|c|c|c|}
\hline & \multicolumn{5}{|c|}{ Dependent Variable: Toilet Construction } \\
\hline Panel A: Social Capital Index BL (All variables) & $(1)$ & $(2)$ & $(3)$ & $(4)$ & $(5)$ \\
\hline Treatment & $\begin{array}{c}.06 \\
(.02)^{* * *}\end{array}$ & $\begin{array}{c}.06 \\
(.02)^{* * *}\end{array}$ & $\begin{array}{c}.06 \\
(.02)^{* * *}\end{array}$ & $\begin{array}{c}.06 \\
(.02)^{* * *}\end{array}$ & $\begin{array}{c}.06 \\
(.02)^{* * *}\end{array}$ \\
\hline Treatment*Village Social Capital Index BL (All) & & $\begin{array}{c}.31 \\
(.14)^{* *}\end{array}$ & $\begin{array}{c}.26 \\
(.14)^{*}\end{array}$ & $\begin{array}{c}.32 \\
(.13)^{* *}\end{array}$ & $\begin{array}{c}.28 \\
(.14)^{* *}\end{array}$ \\
\hline Village Social Capital Index BL (All) & & $\begin{array}{c}.04 \\
(.12)\end{array}$ & $\begin{array}{l}.009 \\
(.13)\end{array}$ & $\begin{array}{c}.09 \\
.(12)\end{array}$ & $\begin{array}{c}.1 \\
(.12)\end{array}$ \\
\hline Treatment*Household Social Capital Index BL (All) & & & & & $\begin{array}{l}.06 \\
(.07)\end{array}$ \\
\hline Household Social Capital Index BL (All) & & & & & $\begin{array}{l}-.02 \\
(.04)\end{array}$ \\
\hline Panel B: Participation Index BL & $(1)$ & $(2)$ & $(3)$ & $(4)$ & $(5)$ \\
\hline Treatment & $\begin{array}{c}.06 \\
(.02)^{* * *}\end{array}$ & $\begin{array}{c}.07 \\
(.02)^{* * *}\end{array}$ & $\begin{array}{c}.08 \\
(.02)^{* * *}\end{array}$ & $\begin{array}{c}.08 \\
(.02)^{* * *}\end{array}$ & $\begin{array}{c}.08 \\
(.02)^{* * *}\end{array}$ \\
\hline Treatment*Village Participation Index BL & & $\begin{array}{c}.22 \\
(.11)^{* *}\end{array}$ & $\begin{array}{c}.24 \\
(.12)^{* *}\end{array}$ & $\begin{array}{c}.32 \\
(.11)^{* * *}\end{array}$ & $\begin{array}{c}.25 \\
(.13)^{* *}\end{array}$ \\
\hline Village Participation Index BL & & $\begin{array}{c}.1 \\
(.13)\end{array}$ & $\begin{array}{l}.07 \\
(.13)\end{array}$ & $\begin{array}{c}.04 \\
(.12)\end{array}$ & $\begin{array}{l}.07 \\
(.12)\end{array}$ \\
\hline Treatment*Household Participation Index BL & & & & & $\begin{array}{l}.08 \\
(.05)\end{array}$ \\
\hline Household Participation Index BL & & & & & $\begin{array}{l}-.03 \\
(.03)\end{array}$ \\
\hline Panel C: Trust Index BL & $(1)$ & $(2)$ & $(3)$ & $(4)$ & $(5)$ \\
\hline Treatment & $\begin{array}{c}.06 \\
(.02)^{* * *}\end{array}$ & $\begin{array}{c}.06 \\
(.02)^{* * *}\end{array}$ & $\begin{array}{c}.06 \\
(.02)^{* * *}\end{array}$ & $\begin{array}{c}.07 \\
(.02)^{* * *}\end{array}$ & $\begin{array}{c}.07 \\
(.02)^{* * *}\end{array}$ \\
\hline Treatment*Village Trust Index BL & & $\begin{array}{l}.04 \\
(.12)\end{array}$ & $\begin{array}{l}.002 \\
(.11)\end{array}$ & $\begin{array}{l}.03 \\
(.09)\end{array}$ & $\begin{array}{c}-.02 \\
(.1)\end{array}$ \\
\hline Village Trust Index BL & & $\begin{array}{l}-.06 \\
(.09)\end{array}$ & $\begin{array}{l}-.06 \\
(.07)\end{array}$ & $\begin{array}{l}-.05 \\
(.09)\end{array}$ & $\begin{array}{l}-.04 \\
(.09)\end{array}$ \\
\hline Treatment*Household Trust Index BL & & & & & $\begin{array}{l}.05 \\
(.03)^{*}\end{array}$ \\
\hline Household Trust Index BL & & & & & $\begin{array}{c}-.006 \\
(.02)\end{array}$ \\
\hline Panel D: Crime/Corruption Index BL & $(1)$ & $(2)$ & $(3)$ & $(4)$ & $(5)$ \\
\hline Treatment & $\begin{array}{c}.06 \\
(.02)^{* * *}\end{array}$ & $\begin{array}{c}.06 \\
(.02)^{* * *}\end{array}$ & $\begin{array}{c}.06 \\
(.02)^{* * *}\end{array}$ & $\begin{array}{c}.07 \\
(.02)^{* * *}\end{array}$ & $\begin{array}{c}.07 \\
(.02)^{* * *}\end{array}$ \\
\hline Treatment*Village Crime/Corruption Index BL & & $\begin{array}{l}.13 \\
(.09)\end{array}$ & $\begin{array}{l}.09 \\
(.12)\end{array}$ & $\begin{array}{l}.06 \\
(.11)\end{array}$ & $\begin{array}{l}.11 \\
(.11)\end{array}$ \\
\hline Village Crime/Corruption Index BL & & $\begin{array}{l}-.02 \\
(.07)\end{array}$ & $\begin{array}{c}-.07 \\
(.1)\end{array}$ & $\begin{array}{l}-.03 \\
(.11)\end{array}$ & $\begin{array}{l}-.05 \\
(.11)\end{array}$ \\
\hline Treatment*Household Crime/Corruption Index BL & & & & & $\begin{array}{l}-.06 \\
(.05)\end{array}$ \\
\hline Household Crime/Corruption Index BL & & & & & $\begin{array}{l}.02 \\
(.02)\end{array}$ \\
\hline Controls: & No & No & Yes & Yes & Yes \\
\hline Sub-district fixed effects & Yes & Yes & Yes & Yes & Yes \\
\hline Mean DV (Treatment=0) & 0.06 & 0.06 & 0.06 & 0.06 & 0.06 \\
\hline Observations & 596 & 596 & 596 & 596 & 596 \\
\hline
\end{tabular}

Notes: These are OLS regressions on the sample of households that did not have private sanitation facilities at baseline. Column 3 also includes household controls (number of male adults, female adults and children in the household, household head's age, educational attainment, per capita household income, and dwelling characteristics) and village controls (village population, percentage of the village which is Muslim, whether there is a paved road to the nearest city, whether there is more than one ethnic group in the village, whether there is TV reception within the village and whether river flows through the village). Columns 4 and 5 include the controls in column 3 plus land 24 ea of the village, percentage of households that are farmers, average educational status of household heads, gini coefficient of per capita income in the village, whether there is a community health center, clinic or hospital within $5 \mathrm{kms}$, whether there is a junior or senior high school within $5 \mathrm{kms}$, and the percentage of households that did not have access to sanitation at baseline. Standard errors are clustered at village level and reported in parentheses. $* * *$ indicates significance at $1 \%$ level, $* *$ at $5 \%$ level, $*$ at $10 \%$ level. 
Table 4: Does social capital impact open defecation?

\begin{tabular}{|c|c|c|c|c|c|}
\hline & \multicolumn{5}{|c|}{ Dependent Variable: Open Defecation Index EL } \\
\hline Panel A: Social Capital Index BL (All indices) & (1) & $(2)$ & $(3)$ & $(4)$ & $(5)$ \\
\hline Treatment & $\begin{array}{c}.08 \\
(.03)^{* * *}\end{array}$ & $\begin{array}{c}-.08 \\
(.03)^{* * *}\end{array}$ & $\begin{array}{c}.09 \\
(.03)^{* * *}\end{array}$ & $\begin{array}{c}-.12 \\
(.04)^{* * *}\end{array}$ & $\begin{array}{c}-.12 \\
(.04)^{* * *}\end{array}$ \\
\hline Treatment*Village Social Capital Index BL (All) & & $\begin{array}{c}-.68 \\
(.2)^{* * *}\end{array}$ & $\begin{array}{l}-.72 \\
(.2)^{* * *}\end{array}$ & $\begin{array}{c}-.63 \\
(.25)^{* *}\end{array}$ & $\begin{array}{c}-.55 \\
(.25)^{* *}\end{array}$ \\
\hline Village Social Capital Index BL (All) & & $\begin{array}{l}.33 \\
(.19)^{*}\end{array}$ & $\begin{array}{l}.35 \\
(.25)\end{array}$ & $\begin{array}{l}.3 \\
(.27)\end{array}$ & $\begin{array}{l}.28 \\
(.27)\end{array}$ \\
\hline Treatment*Household Social Capital Index BL (All) & & & & & $\begin{array}{l}-.12 \\
(.08)\end{array}$ \\
\hline Household Social Capital Index BL (All) & & & & & $\begin{array}{l}.03 \\
(.05)\end{array}$ \\
\hline Panel B: Participation Index BL & $(1)$ & $(2)$ & $(3)$ & $(4)$ & $(5)$ \\
\hline Treatment & $\begin{array}{c}.08 \\
(.03)^{* * *}\end{array}$ & $\begin{array}{c}.08 \\
(.03)^{* * *}\end{array}$ & $\begin{array}{c}-.1 \\
(.03)^{* * *}\end{array}$ & $\begin{array}{c}.12 \\
(.04)^{* * *}\end{array}$ & $\begin{array}{c}-.12 \\
(.04)^{* * *}\end{array}$ \\
\hline Treatment*Village Participation Index BL & & $\begin{array}{l}-.26 \\
(.17)\end{array}$ & $\begin{array}{c}-.39 \\
(.16)^{* *}\end{array}$ & $\begin{array}{c}-.38 \\
(.17)^{* *}\end{array}$ & $\begin{array}{c}-.32 \\
(.18)^{*}\end{array}$ \\
\hline Village Participation Index BL & & $\begin{array}{l}-.07 \\
(.16)\end{array}$ & $\begin{array}{l}-.04 \\
(.19)\end{array}$ & $\begin{array}{l}.11 \\
(.22)\end{array}$ & $\begin{array}{l}.11 \\
(.23)\end{array}$ \\
\hline Treatment*Household Participation Index BL & & & & & $\begin{array}{l}-.06 \\
(.05)\end{array}$ \\
\hline Household Participation Index BL & & & & & $\begin{array}{l}.01 \\
(.03)\end{array}$ \\
\hline Controls & No & No & Yes & Yes & Yes \\
\hline Sub-district fixed effects: & Yes & Yes & Yes & Yes & Yes \\
\hline Mean DV (Treatment $=0$ ) & 0.88 & 0.88 & 0.88 & 0.88 & 0.88 \\
\hline Observations & 596 & 596 & 596 & 596 & 596 \\
\hline
\end{tabular}

Notes: These are OLS regressions from the sample of households that did not have private sanitation facilities at baseline. Column 3 also includes household controls (the number of male adults, female adults and children in the household, the household head's age, educational attainment, per capita household income and dwelling characteristics) and village controls (the village population, the percentage of the village which is Muslim, whether there is a paved road to the nearest city, whether there is more than one ethnic group in the village, whether there is TV reception within the village and whether a river flows through the village). Columns 4 and 5 include the controls in column 3 and additionally controls for the land area of the village, the percentage of households that are farmers, the average educational status of household heads, the gini coefficient of per capita income in the village, whether there is a community health center, clinic or hospital within 5 kms, whether there is a junior or senior high school within $5 \mathrm{kms}$, and the percentage of households that did not have access to sanitation at baseline. Standard errors clustered at the village level and are reported in parentheses. $* * *$ indicates significance at $1 \%$ level, $* *$ at $5 \%$ level, $*$ at $10 \%$ level. 


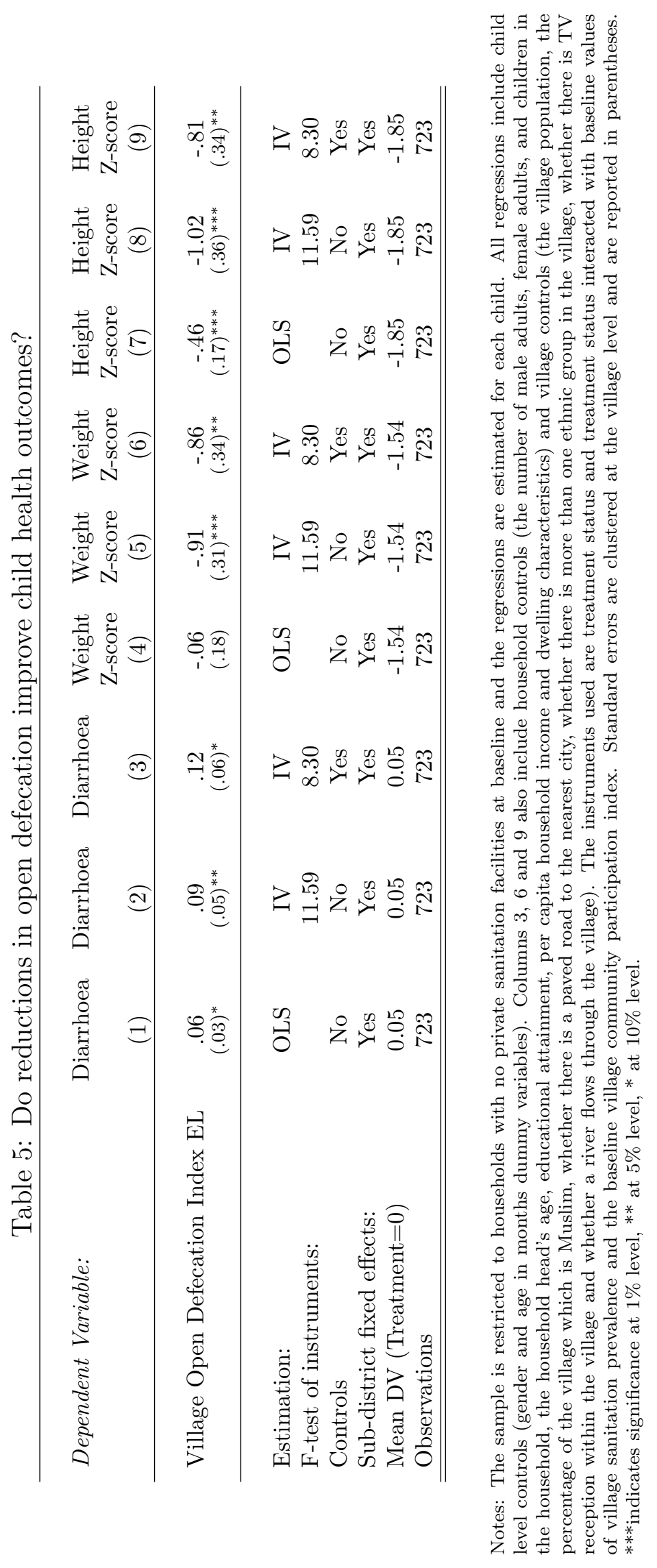


Table 6: Role of Baseline Community Participation in Treatment Communities

\begin{tabular}{|c|c|c|c|}
\hline Dependent Variable: & $\begin{array}{c}\text { Information } \\
\text { Index EL } \\
\text { (1) }\end{array}$ & $\begin{array}{c}\text { Sharing/ } \\
\text { Attendance } \\
\text { Index EL } \\
(2)\end{array}$ & $\begin{array}{l}\text { Sanctions } \\
\text { Index } \\
\text { EL } \\
(3)\end{array}$ \\
\hline Village Participation Index BL & $\begin{array}{l}.13 \\
(.17)\end{array}$ & $\begin{array}{l}.003 \\
(.17)\end{array}$ & $\begin{array}{c}.49 \\
(.2)^{* *}\end{array}$ \\
\hline Sub-district fixed effects: & Yes & Yes & Yes \\
\hline Mean DV (treatment $=0)$ & 0.01 & 0.00 & 0.00 \\
\hline Observations & 721 & 721 & 721 \\
\hline
\end{tabular}

Notes: These are OLS regressions for the entire sample of treatment households. All regressions include household controls (the number of male adults, female adults, and children in the household, the household head's age, educational attainment, per capita household income and dwelling characteristics) and village controls (the village population, the percentage of the village which is Muslim, whether there is a paved road to the nearest city, whether there is more than one ethnic group in the village, whether there is TV reception within the village and whether a river flows through the village). Standard errors clustered at the village level and are reported in parentheses. $* * *$ indicates significance at $1 \%$ level, ${ }^{* *}$ at $5 \%$ level, $*$ at $10 \%$ level.

Table 7: Effect of CLTS Treatment on Endline Social Capital

\begin{tabular}{|c|c|c|c|c|c|c|c|c|}
\hline Dependent Variable: & $\begin{array}{c}\text { Social } \\
\text { Capital } \\
\text { Index EL } \\
(1)\end{array}$ & $\begin{array}{c}\text { Social } \\
\text { Capital } \\
\text { Index EL } \\
(2)\end{array}$ & $\begin{array}{c}\text { Partici- } \\
\text { pation } \\
\text { EL } \\
(3)\end{array}$ & $\begin{array}{c}\text { Partici- } \\
\text { pation } \\
\text { EL } \\
(4)\end{array}$ & $\begin{array}{c}\text { Trust } \\
\text { Index } \\
\text { Index EL } \\
(5)\end{array}$ & $\begin{array}{c}\text { Trust } \\
\text { Index } \\
\text { Index EL } \\
(6)\end{array}$ & $\begin{array}{c}\text { Crime/ } \\
\text { Corruption } \\
\text { Index EL } \\
(7)\end{array}$ & $\begin{array}{c}\text { Crime/ } \\
\text { Corruption } \\
\text { Index EL } \\
(8)\end{array}$ \\
\hline Treatment & $\begin{array}{l}-.001 \\
(.01)\end{array}$ & $\begin{array}{l}-.01 \\
(.01)\end{array}$ & $\begin{array}{l}.02 \\
(.02)\end{array}$ & $\begin{array}{l}.008 \\
(.02)\end{array}$ & $\begin{array}{c}-.03 \\
(.02)^{* *}\end{array}$ & $(-.04)^{* *}$ & $\begin{array}{l}-.003 \\
(.02)\end{array}$ & $\begin{array}{l}-.01 \\
(.02)\end{array}$ \\
\hline Village Social Capital BL (All) & & $(.02)^{* * *}$ & & & & & & \\
\hline Village Participation Index BL & & & & $(.02)^{* * *}$ & & & & \\
\hline Village Trust lndex BL & & & & & & $\begin{array}{l}0.03 \\
(.02)\end{array}$ & & \\
\hline $\begin{array}{l}\text { Village Crime/Corruption } \\
\text { Index BL }\end{array}$ & & & & & & & & $(.03)^{* * *}$ \\
\hline Controls & No & Yes & No & Yes & No & Yes & No & Yes \\
\hline Sub-district effects: & Yes & Yes & Yes & Yes & Yes & Yes & Yes & Yes \\
\hline Mean DV (treatment $=0)$ & 0.00 & 0.00 & 0.00 & 0.00 & 0.00 & 0.00 & 0.00 & 0.00 \\
\hline Observations & 1449 & 1449 & 1449 & 1449 & 1449 & 1449 & 1449 & 1449 \\
\hline
\end{tabular}

Notes: These are OLS regressions for the entire sample of households. Odd numbered columns include household controls (the number of adults and children in the household, the household head's age, educational attainment, per capita household income and dwelling characteristics) and community controls (the baseline community participation index, the community population, the percentage of the community which is Muslim, whether there is a paved road to the nearest city, whether there is more than on ethnic group in the community and whether there is TV access within the village). Standard errors clustered at the village level and are reported in parentheses. $* * *$ indicates significance at $1 \%$ level, ${ }^{* *}$ at $5 \%$ level, ${ }^{*}$ at $10 \%$ level. 


\begin{tabular}{lccc} 
Table 8: Does More Social Capital Ameliorate the Negative Trust Effect? \\
\hline Dependent Variable: & $\begin{array}{c}\text { Participation } \\
\text { Index EL } \\
(1)\end{array}$ & $\begin{array}{c}\text { Trust } \\
\text { Index EL } \\
(2)\end{array}$ & $\begin{array}{c}\text { Crime/Corruption } \\
\text { Index EL } \\
(3)\end{array}$ \\
\hline \hline Treatment & .004 & -.04 & -.01 \\
& $(.02)$ & $(.02)^{* *}$ & $(.02)$ \\
Treat*Village Participation Index BL & .02 & .13 & .01 \\
& $(.09)$ & $(.07)^{*}$ & $(.09)$ \\
Village Participation Index BL & .08 & -.02 & .1 \\
& $(.1)$ & $(.08)$ & $(.08)$ \\
& & & Yes \\
Controls & Yes & Yes & Yes \\
Sub-district fixed effects: & Yes & Yes & 0.00 \\
Mean DV (treatment=0) & 0.00 & 0.00 & 1449 \\
Observations & 1449 & 1449 & \\
\hline \hline
\end{tabular}

Notes: These are OLS regressions for the entire sample of households. All columns include household controls (the number of adults and children in the household, the household head's age, educational attainment, per capita household income and dwelling characteristics) and community controls (the baseline community participation index, the community population, the percentage of the community which is Muslim, whether there is a paved road to the nearest city, whether there is more than on ethnic group in the community and whether there is TV access within the village). Standard errors clustered at the village level and are reported in parentheses. ${ }^{* * *}$ indicates significance at $1 \%$ level, ${ }^{* *}$ at $5 \%$ level, ${ }^{*}$ at $10 \%$ level. 


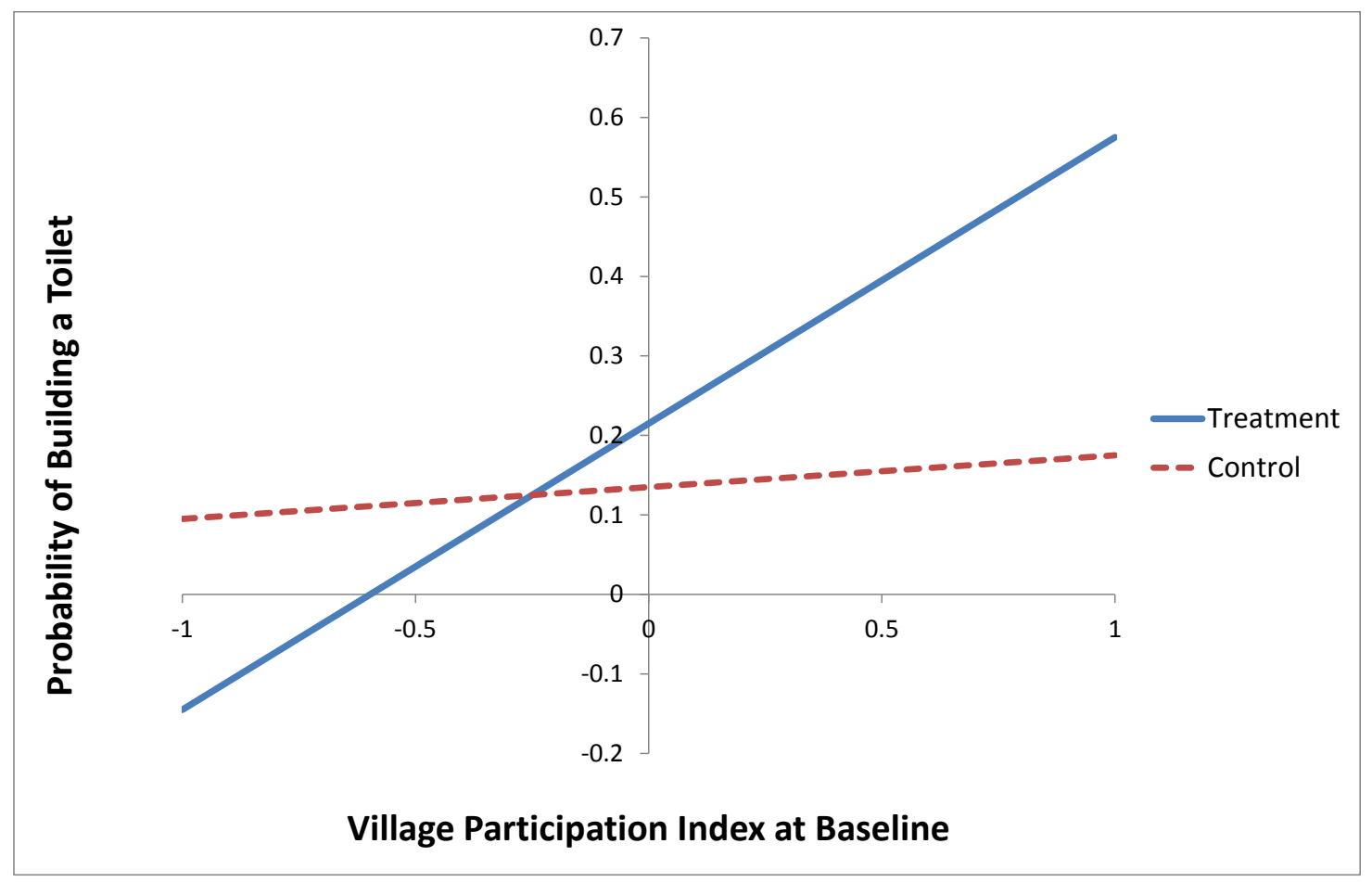

Figure 1: Relationship between Toilet Construction and Baseline Village Participation by Treatment Status 
A Appendix Tables 
Table A1: Balance Table

\begin{tabular}{|c|c|c|c|c|c|c|}
\hline \multirow[t]{2}{*}{ Variables } & \multicolumn{3}{|c|}{ All Households } & \multicolumn{3}{|c|}{ No Sanitation at Baseline } \\
\hline & $\begin{array}{c}\text { Mean } \\
\text { (Treatment) }\end{array}$ & $\begin{array}{c}\text { Mean } \\
\text { (Control) } \\
\end{array}$ & $\begin{array}{c}\mathrm{p} \text {-value } \\
\text { Difference }\end{array}$ & $\begin{array}{c}\text { Mean } \\
\text { (Treatment) }\end{array}$ & $\begin{array}{c}\text { Mean } \\
(\text { Control }) \\
\end{array}$ & $\begin{array}{c}\mathrm{p} \text {-value } \\
\text { Difference }\end{array}$ \\
\hline \multicolumn{7}{|l|}{ Baseline Sanitation Variables: } \\
\hline No sanitation at BL & 0.40 & 0.42 & 0.74 & 1.00 & 1.00 & \\
\hline Faecal disposal $>10 \mathrm{~m}$ from drinking water & 0.81 & 0.85 & 0.11 & 0.91 & 0.93 & 0.40 \\
\hline Access to an improved water source & 0.84 & 0.85 & 0.84 & 0.86 & 0.84 & 0.76 \\
\hline Wash hands after defecation & 0.99 & 0.99 & 0.52 & 0.97 & 0.99 & 0.31 \\
\hline Water available at hand-washing station & 0.57 & 0.54 & 0.56 & 0.24 & 0.24 & 0.99 \\
\hline Soap available at hand-washing station & 0.45 & 0.43 & 0.66 & 0.19 & 0.19 & 0.91 \\
\hline \multicolumn{7}{|l|}{ Baseline Household Control Variables: } \\
\hline Household head's age & 40.23 & 40.12 & 0.89 & 40.11 & 38.45 & 0.13 \\
\hline Household head's educational attainment: & & & & & & \\
\hline Elementary & 0.51 & 0.51 & 0.85 & 0.63 & 0.63 & 0.87 \\
\hline Lower secondary & 0.20 & 0.20 & 0.75 & 0.17 & 0.17 & 0.93 \\
\hline Upper secondary & 0.17 & 0.20 & 0.47 & 0.11 & 0.10 & 0.91 \\
\hline Tertiary & 0.05 & 0.04 & 0.43 & 0.01 & 0.01 & 0.43 \\
\hline \multicolumn{7}{|l|}{ Number of children in the household: } \\
\hline Aged $0-5$ years & 1.15 & 1.13 & 0.33 & 1.13 & 1.07 & $0.01^{* * *}$ \\
\hline Aged $6-10$ years & 0.35 & 0.30 & 0.13 & 0.37 & 0.28 & $0.05^{*}$ \\
\hline Aged $11-17$ years & 0.37 & 0.38 & 0.78 & 0.41 & 0.41 & 0.93 \\
\hline Number of adult males & 1.29 & 1.27 & 0.76 & 1.27 & 1.26 & 0.82 \\
\hline Number of adult females & 1.45 & 1.40 & 0.26 & 1.38 & 1.38 & 0.96 \\
\hline Per capita household income & $3,987,761$ & $3,855,335$ & 0.65 & $2,652,664$ & $2,587,326$ & 0.77 \\
\hline House has a dirt floor & 0.22 & 0.24 & 0.60 & 0.32 & 0.32 & 0.95 \\
\hline House has a tiled floor & 0.05 & 0.06 & 0.49 & 0.03 & 0.04 & 0.82 \\
\hline House has walls of brick or wood & 0.89 & 0.88 & 0.83 & .0 .80 & 0.82 & 0.61 \\
\hline \multicolumn{7}{|l|}{ Baseline Village Control Variables: } \\
\hline Village population & 925.61 & $1,052.51$ & 0.21 & 835.33 & 894.69 & 0.46 \\
\hline$\%$ of the village population that are muslim & 97.72 & 97.26 & 0.68 & 98.61 & 98.41 & 0.77 \\
\hline Paved road to the nearest city & 0.92 & 0.95 & 0.46 & 0.92 & 0.96 & 0.52 \\
\hline More than one ethnic group in the village & 0.69 & 0.69 & 0.98 & 0.75 & 0.78 & 0.81 \\
\hline TV reception & 0.89 & 0.88 & 0.92 & 0.82 & 0.86 & 0.70 \\
\hline Village land area & 63,297 & $33,543.05$ & 0.27 & 109,804 & $22,601.86$ & $0.03^{* *}$ \\
\hline Percentage of households that are farmers & 53.46 & 54.64 & 0.79 & 53.28 & 54.70 & 0.79 \\
\hline Gini coefficient of per capita village income & 0.42 & 0.40 & 0.52 & 0.43 & 0.40 & 0.33 \\
\hline Average household heads' years of education & 10.13 & 10.45 & 0.26 & 9.67 & 10.40 & $0.06^{*}$ \\
\hline A medical facility within $5 \mathrm{kms}$ & 0.98 & 0.98 & 0.96 & 0.97 & 1.00 & 0.31 \\
\hline A secondary school within $5 \mathrm{kms}$ & 0.92 & 1.00 & $0.02^{* *}$ & 0.88 & 1.00 & $0.04 * *$ \\
\hline River runs through village & 0.83 & 0.86 & 0.62 & 0.92 & 0.93 & 0.86 \\
\hline$\%$ of households in village that open defecate & 15.18 & 14.66 & 0.86 & 24.14 & 21.27 & 0.45 \\
\hline Observations & 721 & 728 & & 421 & 307 & \\
\hline
\end{tabular}

Notes: $* * *$ indicates difference is significant at $1 \%$ level, ${ }^{* *}$ at $5 \%$ level, ${ }^{*}$ at $10 \%$ level. 
Table A2: Correlates of Baseline Social Capital

\begin{tabular}{|c|c|c|c|c|}
\hline & $\begin{array}{l}\text { Social Capital } \\
\text { Index BL } \\
\text { (1) }\end{array}$ & $\begin{array}{l}\text { Social Capital } \\
\text { Index BL } \\
(2)\end{array}$ & $\begin{array}{l}\text { Participation } \\
\text { Index BL } \\
(3)\end{array}$ & $\begin{array}{c}\text { Participation } \\
\text { Index BL } \\
(4)\end{array}$ \\
\hline Village Population (/1000) & $\begin{array}{l}-.02 \\
(.025)\end{array}$ & $\begin{array}{c}-.06 \\
(.0272)^{* *}\end{array}$ & $\begin{array}{l}-.04 \\
(.0355)\end{array}$ & $\begin{array}{l}-.06 \\
(.0355)^{*}\end{array}$ \\
\hline \% Village population who are Muslim & $\begin{array}{l}-.002 \\
(.002)\end{array}$ & $\begin{array}{c}-.0002 \\
(.001)\end{array}$ & $\begin{array}{l}-.001 \\
(.004)\end{array}$ & $\begin{array}{l}.0004 \\
(.002)\end{array}$ \\
\hline Paved Road to nearest city & $\begin{array}{l}-.12 \\
(.06)^{* *}\end{array}$ & $\begin{array}{l}.03 \\
(.06)\end{array}$ & $\begin{array}{l}-.18 \\
(.09)^{* *}\end{array}$ & $\begin{array}{c}-.007 \\
(.1)\end{array}$ \\
\hline More than one ethnic group in village & $\begin{array}{l}-.01 \\
(.03)\end{array}$ & $\begin{array}{l}.01 \\
(.02)\end{array}$ & $\begin{array}{l}-.02 \\
(.04)\end{array}$ & $\begin{array}{l}.02 \\
(.03)\end{array}$ \\
\hline TV reception & $\begin{array}{l}.05 \\
(.04)\end{array}$ & $\begin{array}{l}.17 \\
(.1)\end{array}$ & $(.15)$ & $\begin{array}{l}.27 \\
(.14)^{*}\end{array}$ \\
\hline Village Land Area (/1 mill) & $\begin{array}{l}-0.06 \\
(0.09)\end{array}$ & $\begin{array}{l}-0.04 \\
(0.09)\end{array}$ & $\begin{array}{l}-0.09 \\
(0.14)\end{array}$ & $\begin{array}{l}-0.02 \\
(0.13)\end{array}$ \\
\hline$\%$ households that are farmers & $\begin{array}{l}-.001 \\
(.0006)^{* *}\end{array}$ & $\begin{array}{l}-.001 \\
(.0006)^{*}\end{array}$ & $\begin{array}{c}-.002 \\
(.0009)^{* * *}\end{array}$ & $\begin{array}{l}-.003 \\
(.001)^{* * *}\end{array}$ \\
\hline$\%$ of households in village that open defecate & $\begin{array}{l}-.001 \\
(.0009)\end{array}$ & $\begin{array}{l}-.002 \\
(.0009)^{*}\end{array}$ & $\begin{array}{c}-.0009 \\
(.002)\end{array}$ & $\begin{array}{l}-.004 \\
(.001)^{* * *}\end{array}$ \\
\hline Gini coefficient of per capita income & $\begin{array}{l}.05 \\
(.12)\end{array}$ & $\begin{array}{l}.07 \\
(.1)\end{array}$ & $\begin{array}{l}-.03 \\
(.2)\end{array}$ & $\begin{array}{l}-.06 \\
(.17)\end{array}$ \\
\hline Average head of household's years of education & $\begin{array}{l}-.02 \\
(.009)^{* *}\end{array}$ & $\begin{array}{l}.002 \\
(.009)\end{array}$ & $\begin{array}{l}-.03 \\
(.02)^{*}\end{array}$ & $\begin{array}{c}-.006 \\
(.02)\end{array}$ \\
\hline A medical facility within $5 \mathrm{kms}$ & $\begin{array}{l}-.21 \\
(.08)^{* *}\end{array}$ & $\begin{array}{l}-.07 \\
(.09)\end{array}$ & $\begin{array}{l}-.29 \\
(.08)^{* * *}\end{array}$ & $\begin{array}{l}-.12 \\
(.14)\end{array}$ \\
\hline A secondary school within $5 \mathrm{kms}$ & $\begin{array}{l}-.01 \\
(.05)\end{array}$ & $\begin{array}{l}.02 \\
(.04)\end{array}$ & $\begin{array}{l}-.05 \\
(.09)\end{array}$ & $\begin{array}{l}.06 \\
(.06)\end{array}$ \\
\hline Sub-district fixed effects: & No & Yes & No & Yes \\
\hline R-squared & 0.05 & 0.18 & 0.08 & 0.20 \\
\hline Observations & 1449 & 1449 & 1449 & 1449 \\
\hline
\end{tabular}

Notes: These are OLS regressions on the full sample of households. All specifications also include household controls (the number of male adults, female adults and children in the household, the household head's age, educational attainment, per capita household income and dwelling characteristics). Standard errors clustered at the village level and are reported in parentheses. $* * *$ indicates significance at $1 \%$ level, ${ }^{* *}$ at $5 \%$ level, $*$ at $10 \%$ level. 
Table A3: What types of community participation networks matter for program success?

\begin{tabular}{|c|c|c|c|c|c|}
\hline & \multicolumn{5}{|c|}{ Dependent Variable: Toilet Construction } \\
\hline & $(1)$ & $(2)$ & $(3)$ & $(4)$ & $(5)$ \\
\hline Treatment & $\begin{array}{c}1 \\
(.02)^{* * *}\end{array}$ & $\begin{array}{c}.05 \\
(.02)^{* *}\end{array}$ & $\begin{array}{c}.07 \\
(.02)^{* * *}\end{array}$ & $\begin{array}{c}.06 \\
(.02)^{* * *}\end{array}$ & $\begin{array}{c}.06 \\
(.02)^{* * *}\end{array}$ \\
\hline Treat* Village Religious Group & $\begin{array}{c}.21 \\
(.05)^{* * *}\end{array}$ & & & & \\
\hline Village Religious Group & $\begin{array}{l}.02 \\
(.04)\end{array}$ & & & & \\
\hline Treat* Village Women's Group & & $\begin{array}{l}.04 \\
(.04)\end{array}$ & & & \\
\hline Village Women's Group & & $\begin{array}{l}.08 \\
(.05)^{*}\end{array}$ & & & \\
\hline Treat* Village Arisan Group & & & $\begin{array}{c}.07 \\
(.04)^{*}\end{array}$ & & \\
\hline Village Arisan Group & & & $\begin{array}{l}-.01 \\
(.04)\end{array}$ & & \\
\hline Treat* Village No. of Friends Measure & & & & $\begin{array}{l}-.03 \\
(.13)\end{array}$ & \\
\hline Village No. of Friends Measure & & & & $\begin{array}{l}.08 \\
(.1)\end{array}$ & \\
\hline Treat* Village Borrow Money & & & & & $\begin{array}{c}.13 \\
(.07)^{*}\end{array}$ \\
\hline Village Borrow Money & & & & & $\begin{array}{l}-.09 \\
(.05)^{*}\end{array}$ \\
\hline Sub-district fixed effects: & Yes & Yes & Yes & Yes & Yes \\
\hline Mean DV (treatment $=0)$ & 0.06 & 0.06 & 0.06 & 0.06 & 0.06 \\
\hline Observations & 596 & 596 & 596 & 596 & 596 \\
\hline
\end{tabular}

Notes: These are OLS regressions on the sample of households that did not have private sanitation facilities at baseline. All specifications include controls for the baseline value of the dependent variable, in levels and interacted with treatment, household controls (the number of male adults, female adults and children in the household, the household head's age, educational attainment, per capita household income and dwelling characteristics) and village controls (the village population, the percentage of the village which is Muslim, whether there is a paved road to the nearest city, whether there is more than one ethnic group in the village, whether there is TV reception within the village and whether a river flows through the village, the land area of the village, the percentage of households that are farmers, the average educational status of household heads, the gini coefficient of per capita income in the village, whether there is a community health centre, clinic or hospital within 5 kms, whether there is a junior or senior high school within $5 \mathrm{kms}$, and the percentage of households that did not have access to sanitation at baseline). Standard errors clustered at the village level and are reported in parentheses. ${ }^{* * *}$ indicates significance at $1 \%$ level, $* *$ at $5 \%$ level, ${ }^{*}$ at $10 \%$ level. 
Table A4: Influence of Friends Sanitation Situation on Toilet Construction Dependent Variable: Toilet Construction

\begin{tabular}{|c|c|c|}
\hline & $\begin{array}{c}\text { Treatment } \\
\text { Communities } \\
(1)\end{array}$ & $\begin{array}{c}\text { Control } \\
\text { Communities } \\
(2) \\
\end{array}$ \\
\hline Share Friends with Toilet at BL & $\begin{array}{l}.16 \\
(.08)^{*}\end{array}$ & $\begin{array}{l}-.04 \\
(.05)\end{array}$ \\
\hline Share Friends with Toilet at BL*Village Participation Index BL & $\begin{array}{l}.66 \\
(.38)^{*}\end{array}$ & $\begin{array}{l}-.43 \\
(.38)\end{array}$ \\
\hline Controls & Yes & Yes \\
\hline Village Fixed Effects & Yes & Yes \\
\hline Mean DV (treatment $=0)$ & 0.06 & 0.06 \\
\hline Observations & 289 & 307 \\
\hline
\end{tabular}

Notes: This table shows the effect of friends' baseline sanitation facilities on the decision to construct a toilet and how this varies with the baseline level of community participation on the sample of households that did not have private sanitation facilities at baseline. All regressions include village fixed effects and control for household controls (the number of male adults, female adults and children in the household, the household head's age, educational attainment, per capita household income and dwelling characteristics). Standard errors are clustered at the village level and are reported in parentheses. $* * *$ indicates significance at $1 \%$ level, ${ }^{* *}$ at $5 \%$ level, ${ }^{*}$ at $10 \%$ level.

Table A5: Effect of CLTS Treatment on Individual Components of Trust Index

\begin{tabular}{|c|c|c|c|c|c|c|c|c|}
\hline Dependent Variable: & $\begin{array}{c}\text { Return } \\
\text { Money } \\
\text { EL } \\
(1)\end{array}$ & $\begin{array}{c}\text { Ability } \\
\text { Work } \\
\text { Together EL } \\
(2)\end{array}$ & $\begin{array}{c}\text { Wants } \\
\text { to Help } \\
\text { EL } \\
(3)\end{array}$ & $\begin{array}{c}\text { Trust } \\
\text { Other } \\
\text { Ethnic EL } \\
(4)\end{array}$ & $\begin{array}{c}\text { Villages } \\
\text { Work } \\
\text { Together EL } \\
(5)\end{array}$ & $\begin{array}{c}\text { Villagers } \\
\text { Donate } \\
\text { EL } \\
(6)\end{array}$ & $\begin{array}{c}\text { Must } \\
\text { be Cautious } \\
\text { EL } \\
(7)\end{array}$ & $\begin{array}{c}\text { Trusts } \\
\text { Neighbour } \\
\text { EL } \\
(8)\end{array}$ \\
\hline Treatment & $\begin{array}{l}-.07 \\
(.06)\end{array}$ & $\begin{array}{c}-.07 \\
(.04)^{*}\end{array}$ & $\begin{array}{c}-.04 \\
(.01)^{* * *}\end{array}$ & $\begin{array}{l}-.07 \\
(.06)\end{array}$ & $\begin{array}{l}.008 \\
(.009)\end{array}$ & $\begin{array}{l}-.02 \\
(.01)\end{array}$ & $\begin{array}{l}.02 \\
(.05)\end{array}$ & $\begin{array}{l}-.002 \\
(.05)\end{array}$ \\
\hline Controls & Yes & Yes & Yes & Yes & Yes & Yes & Yes & Yes \\
\hline Sub-district FE: & Yes & Yes & Yes & Yes & Yes & Yes & Yes & Yes \\
\hline Mean DV $($ treat $=0)$ & 2.64 & 3.50 & 3.93 & 2.11 & 0.94 & 0.90 & 1.89 & 3.04 \\
\hline Observations & 1449 & 1449 & 1449 & 1449 & 1449 & 1449 & 1449 & 1449 \\
\hline
\end{tabular}

Notes: These are OLS regressions on the sample of all households. All regressions control for household controls (the number of male adults, female adults and children in the household, the household head's age, educational attainment, per capita household income and dwelling characteristics) and village controls (the village population, the percentage of the village which is Muslim, whether there is a paved road to the nearest city, whether there is more than one ethnic group in the village, whether there is TV reception within the village). Standard errors clustered at the village level and are reported in parentheses. ${ }^{* * *}$ indicates significance at $1 \%$ level, ${ }^{* *}$ at $5 \%$ level, ${ }^{*}$ at $10 \%$ level. 